\title{
KINERJA KEPALA SEKOLAH SEBAGAI INSTRUCTIONAL LEADER
}

\author{
${ }^{1)}$ Endang Herawan \\ ${ }^{1}$ Dosen Departemen Administrasi Pendidikan, Fakultas Ilmu Pendidikan \\ Universitas Pendidikan Indonesia \\ Email:endangadpen@upi.edu
}

\begin{abstract}
One of the tasks that mustbe performed by a school principal is the leader. To achieve quality learning, principals in running leadership should be oriented or focus on learning. Leader learning in performing their duties aimed at aspects of the curriculum, PBM, as sessment of learning outcomes, teacher development, creating a conducive environment that allows teachers and guide students can study well. To be able to carry out leadership learning required set of competencies, is to formulate learning objectives, directing and guiding curriculum development, improvement PBM, evaluating the performance of teachers and develop it, build a learning community and continuous improvement and build a community of learners .
\end{abstract}

Keywords: Leadership, Competence, Community.

\section{A. PENDAHULUAN}

Masyarakat dewasa ini menghendaki setiap sekolah mampu memberikan layanan pembelajaran yang berkualitas kepada siswanya.Untuk dapat memenuhi harapan tersebut kepala seyogyanya dalam menjalankan fungsi kepemimpinan hendaknya beroritenasi pada masalah pembelajaran, Artinya adalah aspek pembelajaran menjadi focus utama dari kepemimpinan kepala sekolah. Dengan demikian untuk mewujudkan pembelajaran yang bermutu di sekolah, kepala sekolah selain menjalankan fungsi sebagai manajer, hendaknya berperan sebagaiinstructional leader atau kepemimpinan pembelajaran

\begin{tabular}{lrr}
\multicolumn{1}{c}{ Kepala } & sekolah & yang \\
melaksanakan & kepemimpinan \\
pembelajaran sebagian besar waktunya \\
akan difokuskan pada kegiatan yang \\
bisa meningkatkan mutu pembelajaran \\
pembelajaran, $\quad$ seperti: dalam \\
$\begin{array}{l}\text { pengembangan kurikulum, perbaikan } \\
\text { dan pengembangan PBM, evaluasi dan }\end{array}$
\end{tabular}

pengembangan kinerja guru, membangun komunitas pembelajaran dan melakukan perbaikan terus-menerus kurikulum, Kepemimpinan pembelajaran, merupakan model kepemimpinan yang tepat dilakukan oleh kepala sekolah, hal ini sesuai dengan fungsi dan misi utama sekolah adalah melaksanakan pembelajaran,yaitu untuk mendidik semua siswa dan memberikan kesempatan kepada mereka untuk tumbuh, dengan memerikan kesempatan pada siswa untuk memperolah pengetahuan, keterampilan, dan nilainilai yang diperlukan, yang bisa dijadikan bekal dalam kehidupan mereka pada waktu yang akan datang yang penuh dengan tantangan.Memperhatikan fungsi utama sekolah seperti itu maka setiap kepala sekolah sebaiknya melaksanakan model kepemimpinan pembelajaran.

\section{B. KAJIAN LITERATUR}

Konsep Kepemimpinan Pembelajaran 
Seorang kepala sekolah jika dalam menjalankan fungsi kepemimpinnya berorientasi kepada masalah pembelajaran, ini menunjukkan bahwa ia sedang menjalan peran sebagai pemimpin pembelajaran. Oleh karena itu dalam menjalankan peran ini kepala sekolah akan menaruh perhatian yang tinggi pada masalah kurikulum, proses belajar mengajar, penilaian hasil belajar serta pengembangan guru. Menurut Daresh dan Playco (dalam Daryanto, 2011) mendefinisikan kepemimpinan pembelajaran sebagai upaya memimpin para guru agar amengajar lebih baik, yang pada gilirannya dapat memperbaiki prestasi belajar siswa.Menurut Daryanto (2011) Kepemimpinan pembelajaran atau kepemimpinan instruksional adalah kepemimpinan yang memfokuskan/menekankan pada pembelajaran yang komponenkomponennya meliputi kurikulum, proses belajar mengajar, asesmen (penilaian hasil belajar), penilaian serta pengembangan guru, layanan prima dalam pembelajaran, dan pembangunan komunitas belajar di sekolah. Petterson (Daryanto,2011) memberikan definisi yang komprehensif tentang kepemimpinan pembelajaran, yaitu:(1) kepala sekolah mensosialisasikan dan menanamkan isi dan makna visi sekolahnya dengan baik (2) kepala sekolah melibatkan pemangku kepentingan dalam pengelolaan sekolah (3) kepala sekolah memberikan dukungan kepada pembelajaran (4) kepala sekolah melakukan pemantuan tehadap proses belajar mengajar dan (5) kepala sekolah berperan sebagai fasilitator. MenurutDaryanto(2011) tujuan utama kepemimpinan pembelajaran adalah:" memberikan layanan prima kepada semua siswa agar mereka mampu mengembangkan potensi kualitas dasar dan kualitas instrumentalnya untuk menghadapi masa depan yang belum diketahui dan sarat dengan tantangan yang sangat turbulen.'Lebih lanjut dikemukan pada dasarnya kepemimpinan pembelajaran untuk memfasilitas pembelajaran, agar siswanya bisa meningkat prestasi belajarnya, meningkatnyakepuasan belajarnya, meningkat motivasi belajar, meningkat keingintahuannya, kreativitasnya, inovasinya, jiwa kewirausahaannya, dam meningkat kesadarannya untuk belajar secara terus-menerus sepanjang hayat karena ilmu pengetahuan dan teknologi serta seni berkembang dengan pesat.

\section{Pentingnya Kepemimpinan Pembeajaran}

Banyak tugas yang harus
dilakukan oleh kepala sekolah penanggung jawab penyelenggaraan pendidikan di sekolah, yaitu sebagai manajer, supervisor dan sebagai pemimpin.Mengingat tugas yang bersifat administrasi dan manajerial begitu banyak yang harus dilakukan oleh kepala sekolah, maka sebagian besar waktu dan tenaganya tercurah untuk menyelesaikan tugas yang terkait dengan masalah manajerial tersebut.Hasil penelitian Stronge (dalam Daryanto,2011) menunjukkan bahwa seluruh dari pekerjaan yang harus dilaksanakan oleh kepala sekolah hanya $10 \%$ persen yang dialokasikan untuk kepemimpinan pembelajaran.Alasannya diantaranya adalah banyak kegiatan administrates yang dilaksanakan. Padahal kepemimpinan yang berfokus pada pembelajaran saat ini perlu mendapatkan perhatian, hal ini karena 
pada umumnya masyarakat senantiasa menuntut layanan pembelajaran yang berkualitas yang diberikan oleh sekolah, melalui kegiatan pembelajaran yang dilakukan oleh para guru.

\section{Banyak hasil penelitian yang menunjukkan pentingnya kepemimpinan pembelajaran dalam menciptakan sekolah efektif, seperti dikemukakan oleh Buffie (Kemdiknas,2011) yang menyatakan:If our school are to improve, we must redefine the principal's role and move instructional leadership to the forefront'Demikian Hallinger dan Heck (Kemdiknas 2011) yang mengemukakan beberapa penelitian empiric tentang peran kepemimpinan pembelajaran dalam menghasilkan capaian lulusan yang baik. Hasil penelitian menyimpulkan bahwa walaupun kepemimpinan pembelajaran tidak secara langsung berkaitan dengan kegiatan pembelajaran namun berpengaruh besar terhadap hasil pembelajaran.Dalam kepemimpinan pembelajaran yang dilakukan oleh kepala sekolah diwujudkan dalam bentuk perilaku, seperti merumuskan dan mengkomunikasikan tujuan, memantau, mendampingi dan memberikan umpan balik dalama pembelajaran, membangun iklim akadmik yang kondusif serta memfasilitas yang memungkinkan terjadi komunikasi antar staf yang ada di sekolah.}

Meperhatikan berbagai pendapat dan hasil penelitian, tampaknya tidak bisa dipungkiri bahwa kepemimpinan pembelajaran sangat penting untuk ditetrapkan di sekolah karena disebut sebelumnya bahwa kepemimpinan pembelajaran berkontribusi sangat signifikan terhadap peningkatan prestasi belajar siswa.Kepemimpinan pembelajaran mampu memberikan dorongan dan arah terhadap warga sekolah untk meningkatkan prestasi belajar siswanya.Kepemimpinan pembelajaran juga mampu memfokuskan kegiatan-kegiatan warganya untuk menuju pencapaian visi, misi, dan tujuan sekolah.Kepemimpinan pembelajaran penting diterapkan disekolah karena kemampuannya dalam membangun komunitas belajar wargganya dan bahkan mampu menjadikan sekolahnya sebagai sekolah belajar (Learnig School). Seperti telah dikemukakan di atas Kepemimpinan pembelajaran yang dilakukan oleh kepala sekolah tidak secara langsung berhubungan dengan kegiatan belajar di kelas, tetapi perilaku yang dilakukan oleh kepala bisa memberikan pengaruh yang besar terhadap efektivitasbelajar siswa, yang pada gilirannya akan menghasilkan hasil belajar siswa yang baik, Untuk itu sudah selayaknya peran kepemimpinan pembelajaran memperoleh porsi waktu yang lebih besar dibandingkan dengan peran-peran lain. Peran-peran yang lain bukan tidak penting, akan tetapi peran kepemimpinan pembelajaran peru mendapat perhatian yang lebih.

\section{METODE PENELITIAN}

Studi ini menggunakan metode kepustakaan mengenai kepemimpinan yang harus dilaksanakan oleh Kepala Sekolah, pada semua jenjang pendidikan di wilayah Kota Bandung.

\section{HASIL DAN PEMB AHASAN}

\section{Implementasi Kepemimpinan Pembelajaran}


Sekolah merupakan salah satu tempat dilaksanakannya kegiatan pembelajaran. Kegiatan pembelajaran yang dilaksanakan di sekolah ditujukan untuk meningkatkan dan mengembangkan pengetahuan, keterampilan maupun sikap.Keberhasilan sekolah dalam menyelenggarakan proses pembelajaran yang berkualitas tidak dapat dipisahkan dari kepemimpinan yang dilakukan oleh kepala sekolah, karena kepala sekolah merupakan administrator yang bertanggung jawab penuh terhadap keberhasilan belajar setiap peserta didiknya, dengan menyediakan fasilitas, lingkungan belajar, dan program pembelajaran yang memungkinkan siswa bisa berkembang dengan baik.

Sebagai pemimpin pendidikan, kepala sekolah seyogyanya banyak menaruh perhatian terhadap masalah pembelajaran, karena fungsi utama sekolah adalah melayani siswa dalam kegiatan belajar dan keberhasilan belajar siswa tidak bisa dipisahkan dari kepemimpinan kepala sekolah, bahkan dalam salah standar kerja kepala sekolah yang ditetapkan oleh ISLLC (The Interstate School Leaders Licebsure Consortium)

(Richard Gordon, Judy A.Alston dan Petra Snowden,2007)menyatakan:

"Aschool administrator is an educational leader who promotes the success of all students by advocating, nurturing, and sustaining a school culture and instrucyional program conducive to student learning and staff professional growth."

Mengingat tanggung jawab kepala sekolah begitu besar terhadap keberhasilan belajar siswa, maka kepala sekolah hendaknya menaruh perhatian yang tinggi terhadap masalah ini, kepala sekolah dituntut untuk menjadi pemimpin yang memiliki orientasi terhadap masalah pembelajaran, yaitu pemimpin yang mempunyai perhatian yang tinggi, terhadap proses dan hasil belajar siswa, untuk mewujudkan hal ini masalah mengajar dan belajar hendaknya menjadi perhatian utama kepala sekolah, di samping aspek manajerial sekolah. Untuk menilai apakah seorang kepala sekolahdapat diukur dengan mengajaukan beberapa pertanyaan, seperti yang dikemukakan oleh Ronald W.Rebore dan Angela L.E.Walmsley (2007), yaitu:

1. Apakah administrator memulai dengan melakukan analisis kerja siswa atau test prestasi. Hasil test akan dijadikan dasar dalam melihat metoda-metoda mana yang mungkin perlu dilakukan perubahan.

2. Apakah administrator menetapkan seperangkat rencana perbaikan pengajaran yang meliputi tujuan, harapan dan batas waktu

3. Apakah rencana ini mencakup cara-cara yang tepat untuk menganalisis data tentang bagaimana pengajaran harus diubah

4. Apakah administrator atau pemimpin pembelajaran menolong guru dalam penetapan model pembelajaran ?

5. Apakah administrator menaruh perhatian terhadap saran-saran dan rencana-rencana untuk memperbaiki strategi pembelajaran di sekolah? 
Apakah administrator menaruh perhatian dalam evaluasi terhadap guru?

6. Apakah administrator menjelaskan atau mendiskusikan data atau hasil belajar siswa dengan guru untuk menujukkan bagaimana evaluasi pengajaran diperbaiki?

7. Pada akhir tahun akademik, administrator mencurahkan perhatian dengan menyediakan secara personal untuk mengarahkan atau mengembangkan guru dalam mengajar?

8. Pada akhir tahun akademik berapa banyak waktu digunakan administrator untuk bekerja yang diarahkan pada perbaikan dan pengembangan kurikulum

9. Seberapa sering administrator mengobservasi guru dalam menoca metoda pembelajaran yang baru atau melakukan monitoring terhadap keseluruhan kegiatan di kelas yang dapat memberikan gambaran menyeluruh mengenai kegiatan belajar di sekolah.

Sejalan dengan pendapat di atas, seorang kepala sekolah yang menerapkan kepempinan pembelajaran, dapat dilihat dari beberapa aktivitas berikut:

1. Memfasilitas penyusunan tujuan pembeljaran dan standar pembelajaran

2. Melakukan sosialisasi tujuan pembelajaran dan standar pembeljaran

3. Memfasilitasi pembentukan kelompok kerja guru
4. Menerapkan ekspektasi yang tinggi

5. Melakukan evaluasi kinerja guru dan tindak lanjut pengembangannya

6. Membentuk kultur sekolah yang kondusif bagi pembelajaran

7. Membangun learning person dan learning school

8. Menyediakan sebagian besar waktu untuk pembelajaran dan selalu mempunyai waktu untuk guru dan siswanya

9. Melayani dengan prima kepada guru, siswa dan orang tua

10. Melakukan koordinasi terhadap guru, siswa dan orang tua siswa

11. Melakukan monitoring dan evaluasi terhadap keberhasilan pembelajaran akibat penerapan kepemimpinan pembelajaran. (Daryanto,2011)

Memperhatikan berbagai pendapat dan hasil penelitian, seperti yang telah dikemukakan pada bagian awal tulisan ini, tampak bahwa kepemimpinan instruksional yang dilakukan oleh kepala sekolah memberikan kontribusi yang signifikan terhadap keberhasilan belajar siswa, oleh karena sudah saatnya kepala sekolah menyediakan waktu dan tanaga yang lebih banyak untuk melaskanakan model kepemimpinan ini. Untuk melaksanakan kepemimpinan instrusional dengan baik tidak bisa dilakukan secara tergesa-gesa, sebab jika dilakukan seperti itu tidak memberikan manfaat bagi peningkatan hasil belajar siswa. Karena itu Mc Ewan menyarakan tujuh langkah untuk melaksanakan kepemimpinan 
instruksional yang efektif, yaitu: (1) Establish clear instructional goal (2) Be there for your staff (3)Create a school and climate conducive to learning;(4) Communicate the vision and mission of your school (5) Set high expectations for your staf (6) Develop teacher leaders (7) Maintain positive attitude toward students, staff and parents

\section{Kompetensi Kepemimpinan Pembelajaran}

Memperhatikan kegiatan yang dilakukan oleh kepala sekolah yang melaksanakan kepemimpinan pembelajaran, maka untuk melakukan kepemimpinan tersebut seorang kepala sekolah harus memiliki kompetensi yang terkait dengan pembelajaran.Ia hendaknya memiliki pengetahuan dan keterampilan yang mendalam terkait dengan proses pembelajaran. Kompetensi ini sangat penting karena kegiatan utama di sekolah adalah melaksanakan pembelajaran.Untuk itu sudah saatnya seorang kepala dalam menjalankan fungsinya tidak cukup hanya memiliki komtensi manajerial, juga memiliki kompetensi kepemimpinan yang di fokuskan pada masalah pembelajaran.

Kompetensi kepala sekolah pada dasarnya berkaitan pengetahuan, kemampian dan keterampilan yang perlu dimiliki kepala sekolah. Menurut Daryanto (2013) kompetensi yang harus dimiliki oleh kepala sekolah sebagai pemimpin pembelajaran adalah sebagai berikut:

1. Merumuskan dan Mengartikulasikan Pembelajaran
2. Mengarahkan dan Membimbing Pengembangan Kurikulum

3. Membimbing Pengembangan dan Perbaikan Proses Belajar Mengajar

4. Mengevaluasi Kinerja Guru dan Mengembangkannya

5. Membangun Komunitas Pembelajaran

6. Menerapkan Kepemimpinan Visioner dan Situasional

7. Melayani Siswa Dengan Prima

8. Melakukan Perbaikan secara Terus-menerus

9. Menerapkan Karakteristik Kepala Sekolah Efektif

10. Membangun Warga Sekolah agar Pro-Perubahan

11. Membangun Teamwork yang Kompak

12. Memberi Contoh dan Menginspirasi Warga Sekolah

\section{E. SIMPULAN DAN REKOMENDASI}

Kepemimpinan pembelajaran merupakan kepemimpinan yang berorientasi pada peningkatan mutu pembelajaran.Dalam melaksanakan kepemimpinan pembelajaran, kepala sekolah akan menyediakan sebagian besar waktuya untuk perbaikan dan pengembangan mutu pembelajaran. Kegiatan yang dilakukan diantaranya ditujukan pada perbaikan dan pengembangan kuriukulum, PBM, mengevaluasi dan mengembangkan kinerja guru, memfasilitas dan melayani guru dan siswa dengan baik, mengembangkan budaya yang kondusif bagi pembelajaran, serta melakukan koordinasi dengan guru, siswa dan orang tua dalam upaya perbaikan mutu pembelajaran. 
PEDAGOGIA : Jurnal Ilmu Pendidikan

\section{F. REFERENSI}

Daryanto (2011) Kepala Sekolah sebagai Pemimpin Pembelajaran, Penerbit Gava Media, Yogyakarta.

Gordon,Richard, Alson,Judi A and Snowden (2007) School Leadership \& Administration. McGraw Hill.

Kementrian Pendidikan Nasional (2011) Kepemimpinan Pembelajaran: Materi Penguatan Kompetensi Kepala Sekolah, Jakarta.
Lunenburg, Fred C(2006) The

Principalship: Vision to Action, Wadsworth Cengage Learning

McEwan (2002) Seven Steps to Effective Instructional Leadership.Second Edition.TheMcEwan-Adkins Group.

Rebore,Ronald W and E.Walmsley,Angela L (2007) $A n$ Evidence-Based Approach to the Practice Of Educational Leadership. Pears 